\title{
16 \\ My Time with Autism Speaks
}

\author{
John Elder Robison
}

I didn't know much about autism when I began my journey as an advocate. What I knew was my own life, much of which had felt pretty crummy. Yet I had stayed the course, leaving home, learning to make a living, and figuring out how to be an adult in America. At some point I realized I had done ok, despite my marginal childhood, and I started looking for a way to give something back to the community.

At the time my sense of community was local; defined as the area in Western Massachusetts where I'd grown up. By the early 90s I was in my 30 s, with a wife and a young son, and I knew there must be millions of young people growing up marginalized, as I had been. Some were abused, others abandoned. I wondered who spoke to them, and if anyone told them life can get better when we grow older. That was the start of my advocacy.

A friend of a friend invited me to a school where I talked with at-risk kids. Another friend invited me to the local jail where I met people in a

J. E. Robison ( $\square)$

Amherst, MA, USA 
pre-release program. I made several unforgettable visits to Brightside, a Catholic organization that sheltered teens who were victims of abuse and neglect. Having grown up in those circumstances myself I understood the pain of those kids.

My message was that we can move beyond childhood traumas and become successful adults. We are not predestined for jail or the street. Even without college credentials (which were out of reach for me and many of them) I'd been successful (at building a business repairing and restoring cars), and if I could find a wife, get a job, or establish a business, they could too.

In the midst of that advocacy I learned I am autistic. A therapist who'd gotten to know me shared that insight, essentially out of the blue. That was a stunning discovery for me. For the first time, I was presented with a non-judgmental explanation for so many of the challenges of my life. Later I would come to see how autism didn't just disable me-it also helped me with unusual powers of focus, concentration, and sensory sensitivity.

When I first heard I was autistic, I was disbelieving because I imagined autism as total disability and I didn't see myself that way. But as I read Tony Attwood's book Asperger Syndrome [1] I realized the therapist was right. The description from the book was me, point by point, and that insight was enough to open my eyes, and begin a process of self-improvement that continues today. That informal diagnosis has been confirmed by the Autism Diagnostic Observation Scale [2] and other processes at autism clinics. All opened windows into my mind, and how I'm the same and different from others around me.

Today I know that people of my generation were seldom diagnosed with autism if we could talk, and there is a whole generation of people like me, who grew up without a proper diagnosis. In school we were said to be emotionally disturbed, oppositional, lazy, or stupid. The problem was, those descriptors didn't lead to therapies that were very useful for someone like me. They also predisposed others to a rather negative view of individuals who were "different."

Once I learned about autism I realized there must be many other young autistics just like me. I felt I had a message for them, but did not know how to find them. In 2006 I decided to share my thoughts in a book. That 
narrative became Look Me in the Eye [3] and its publication connected me to autistic people all over the world.

Readers looked to me as an expert on autism, but I wasn't an expert in the traditional sense. I had never studied autism in the way a teacher or psychologist might. Yet I had a lifetime's experience being autistic. To the extent my traits were characteristic of autistic people, I had an inside understanding of them.

Today autistic people are visible everywhere, but that was not the case a decade ago. We existed in the same numbers but we were invisible. Most adults were like me-undiagnosed. Children and adults who were diagnosed were often ashamed because autism had the reputation of being a terrible disability. Few were willing to step forward and say, Look at me! I'm autistic!

Yet some people did just that. Daniel Tammet released a bestselling book (Born on a Blue Day) [4] about being autistic a few months before my own came out. Temple Grandin and Margaret Scariano [5], Donna Williams [6], and Stephen Shore [7] had published stories previously. All of us were unique in terms of our interests and abilities, but we had this in common: We recognized that autism was a way of being, not a disease to be cured, and we should make our best life as autistic adults.

That viewpoint stood at odds with an emerging community of parents whose kids were being diagnosed in increasing numbers. Changes in the diagnostic standards and evolving awareness resulted in an explosion of diagnoses, and at the time, many assumed autism itself was becoming an epidemic. Some parents seized on the idea that their kids were injured by vaccine, and they talked about cure and prevention.

When Look Me in the Eye went on sale it competed with another newly released book, Louder Than Words [8], which told the story of a child who was supposedly rendered autistic by vaccine. Both books were bestsellers in the autism community but their messages could not have been more different.

After my first book came out I heard from a number of autism organizations, the largest of which was Autism Speaks. They were newly founded, and already controversial when Look Me in the Eye was published. Their portrayal of autism was that of a monster that ruined marriages and stole 
children. While that played well for fundraising, it was challenged from the beginning by autistic people, who found that kind of talk offensive.

My own book and life story were about building my best life, just the way I was. Having learned through study that autism is a stable neurological difference, not subject to cure, I saw no other sensible course of action. When I read the narratives that were emerging I wondered how much proposed research would possibly benefit people like me. They were focused on finding a cause so they could find a cure. I saw that as totally irrelevant to an autistic person like me. My problems were how to get through school, how to find jobs, and how to sustain relationships.

As I met more autistic people I came to see how some seem far more impaired than me. I saw families where one person was autistic with no trace of autism elsewhere in the family tree. Other families seemed full of autistic people, in every generation. The cause of autism in my case and some others seemed evident-it was woven into our family tree. It wasn't so clear in some of the other families. That opened my eyes to the idea there may be many "autisms" and many paths into this thing we call autism.

Scientists began writing me as soon as my book was announced. They were eager to find autistic adults who could talk about their ideas for autism research. Those conversations led to my joining advisory boards at universities, at hospitals, and in government. It was there I began meeting autism scientists and policymakers.

In December of 2007, University of Washington child psychologist Geraldine Dawson was named Chief Science Officer of Autism Speaks. After reading my book she sought my input on the direction of autism science. I became the first autistic person to advise Autism Speaks on research to serve autistic people.

By that time I had visited a larger number of autism schools and programs, and talked to countless autistic individuals. One thing that came through very clearly was that we needed help with independent living. For some of us, that meant help with organization. For others we needed strategies to manage sensory sensitivities. Some needed help communicating with the non-autistic public around them.

As I began talking to autism researchers I realized I did not have to be a scientist to have a valuable perspective on autism research. My life as an 
autistic person allowed me to put proposed research in perspective with a key test: What would this mean to someone like me? All too often, proposed studies had no beneficial connection to actual autistic people.

That bothered me a lot, particularly as I learned about the breadth of medical problems afflicting autistic people. For example, epilepsy is managed among the non-autistic population but it's seemingly uncontrollable for many autistics. Many of us live with severe gastro-intestinal issues. Anxiety and depression are constant companions for most of us. Those should have been hot topics for research, but they were not.

When I looked at the research Autism Speaks was funding, I saw next to nothing that had potential to resolve the problems I saw among autistics. Instead they were heavily focused on basic genetics and biology. To me, the disconnect was obvious even as the researchers defended their current courses of action.

From the beginning, autistic people were skeptical of my involvement. Some asked why the science community would pay attention to me, a lone autistic who was not even a scientist. Others asked how I could have anything to do with a group that said such awful things about autistic people. The language Autism Speaks used to describe autism and autistic people was very troubling, but I believed they might change their message once exposed to actual autistic adults. Staffers like Dawson seemed to share that belief. In hindsight I see that thinking was naive. It was hard to imagine myself as diseased or damaged, but I understood those words made people open their wallets and I knew our community needed help.

My involvement was limited to recommending courses of research. I had nothing to do with Autism Speaks public statements. It always troubled me when people in the community thought I was an Autism Speaks employee or spokesperson, because I was never either of those things. It embarrassed me to be associated with them, but at the time they were the largest private funder of autism research in the USA and I thought my impact there might be more impactful than at a smaller organization.

I continued to advise Autism Speaks on science, and I also continued my service on autism committees at the National Institutes of Health (NIH), the Centers for Disease Control (CDC), and the Department of Defense. Of those groups, Autism Speaks was always the most controversial. I often 
wondered if it was worth staying involved, but I kept harboring a hope they would change their rhetoric.

Then in 2009 [9] Autism Speaks released its now infamous I Am Autism video which characterized autism as a monster, destroying lives and families. As an autistic person it was hard to see that video as anything but a demonization of the essence of what I am. Thousands agreed, and the ensuing public relations debacle highlighted the widening gulf between certain parents and the emergent community of autistic adults. Parents who imagined themselves as victims of the "autism monster" justified themselves by saying autism in people like me was somehow different, even as the evolving science said that wasn't true.

There was little doubt that I was less disabled than some other autistics, but people vary in every community, and one thing we autistics tend to agree on is our perception of ourselves: we tend to feel less disabled than outside observers judge us to be. I've met a few autistics who think autism is a horrible disability and want a cure, but most of us accept that we are what we are, and do the best we can.

I tried very hard to deliver this message to parents inside and outside of Autism Speaks. In addition to being an autistic person, I was a parent of an autistic son, and I thought I understood how they felt, even if I did think some of their ideas were unhealthy and counterproductive.

In July of 2012, I attended a strategic planning meeting for Autism Speaks in San Francisco. I sat in a room with a dozen esteemed scientists from some of the most prestigious institutions in the world. At that meeting, I proposed that we ask the Autism Speaks governing board to drop the word "cure" from its mission statement. The scientists were all in agreement. Instead, we proposed that we funded research to understand the biological basis of autism and how we might relieve specific aspects of autistic disability. The scientists agreed that no one was researching the broad idea of "cure," and evidence suggested "cure" was not a realistic goal. Remediation of disability is a realistic goal.

After the meeting I expected to hear something from Geri Dawson. Perhaps they'd want me to attend their board meeting, to explain this proposed mission change. The main Autism Speaks board meeting came and went, and nothing happened. I called Geri. "They were not ready to 
hear that," she told me. The resolution had never even been discussed. I was deeply disappointed, and sad.

A few months later Geri left for a new job running the autism center at Duke University. I was sorry to see her go, but I understood as I shared her frustration with the group's fixation on what I believe we both saw as unhealthy ideas. Rob Ring-a former pharmaceutical executive-was named to take her place.

In October of that year (2013), Autism Speaks announced an autism summit to be held in Washington, DC. Significantly, there was not a single autistic person scheduled for attendance. Then in early November Autism Speaks founder Suzanne Wright followed that up with a truly horrific oped. In it, she suggested that millions of autistic people were "lost," taken from society by the monster autism. She said families, and people like me, were "barely living." The response from autistic people was predictable.

I found her article extremely offensive. It made me think of the $I \mathrm{Am}$ Autism piece they had published four years previously. Worst of all, people in the autism community blamed me for being complicit in the newest Autism Speaks debacle. More than a hundred people wrote me to ask how I could be associated with an organization that promulgated ideas like Wright's.

That was a question I could not answer, because I felt the same way. In addition, I felt a deep sadness, realizing my four years of advocacy work within the organization had not made one bit of difference to the Wrights, who headed the organization. I wrote a letter to Liz Feld, the president.

In my letter, I said:

Autism Speaks is never going to be accepted by the broader community of autistic people if they continue the fear-mongering and "sick child" talk...This kind of talk does not do any of us any good.

The idea that [Mrs. Wright] would once again convene a "summit" without any meaningful autistic representation is extremely troubling to me, particularly because we've covered this issue before.

I'm starting to feel like Mrs. Wright is in a very different place than most of the people I see in the autism community...Is Autism Speaks going to 
be able to shift its focus away from her "diseased child" model to focus on consulting with autistic people of all ages... about how their needs might best be served, in a non fear driven environment?

After two days without an answer, I made my decision. On November 13, 2013, on my way to deliver an autism talk in Grand Rapids, Michigan, I wrote a resignation letter. I sent it to Liz Feld's email and I also posted it on my blog (http://jerobison.blogspot.com). The reaction from the autism community was swift.

Most commenters supported my decision to stand up for my beliefs. Online comments (there were over 200 on the blog post alone) were critical of the ideas expressed by Mrs. Wright and of Autism Speaks for continuing to give her views a home.

There were others, though, who expressed solidarity with Mrs. Wright's ideas. Reading their comments, most seemed to be parents who blamed autism for stealing their own children. While I understood how parents might feel that way, I had spoken about how unhealthy that kind of thinking was, both for the families and for the autistic children. Yet it persists in a portion of the community to this day.

I hoped my departure would precipitate some kind of action, but Autism Speaks remained silent on that issue. A number of staffers spoke to me privately, expressing sadness or regret over my decision to leave. They all seemed to understand how I felt. In the past five years many have moved on to other jobs.

Autism Speaks' research portfolio remains heavily weighted toward biology and genetics, and studies that are unlikely to materially benefit this generation of autistic people. I've come to see disagreements with this view as illustrative of the disconnect between what we autistics say we want and need, and what researchers say they should study to help us. It's one reason we autistics need more influence over the research agenda.

The organization's silence led me to consider whether I overestimated my importance to the group. Geri Dawson and the scientists were sincere in seeking my input and I feel we learned much from each other. Yet the Wrights seemed to exist in a separate world, and I don't know if they even knew who I was. I'd been the only autistic person to have a voice in science, but that did not seem to make a lasting difference. I'd spoken 
often, but I wasn't heard by the people in power. Meanwhile, I gained a false confidence as lower-level staffers agreed with my positions. None of us had any influence with the leaders. As time passed and I reflected, I realized Autism Speaks was misnamed. They do not speak for autism, or autistic people, and they never did.

Their founder was a media executive; their name a marketer's creation. Many of the staff described themselves as non-profit professionals, and none of the senior people were autistic. They were very effective at fundraising, and painting a picture of autism that elicited widespread sympathy.

Autism-as-tragedy helped them raise hundreds of millions of dollars. Groups like Charity Watch reported that they spent lavishly on themselves and their organization compared to other medical nonprofits. Their annual reports told a sad story. Monies raised locally paid headquarter's salaries and supported distant researchers. Very little returned to the communities who raised the funds. Perhaps it's all about the money, I thought, and my ideas of acceptance and fitting in are not a basis for tens of millions in donations the way "stolen children" and "ruined families" are.

I had imagined I was making a difference on their science board, but the Wrights called the shots when it came to investing the organization's money, and the research I had advocated for took a back seat to the Wright's agenda, which appeared to be biology and cure. Had I been able, I would have made different choices.

Autism Speaks would probably disagree with me, but I felt then and feel today that their focus on causes and cures did very little to help the millions living with the reality of autism. From the beginning of my autism advocacy, I have kept that goal in sharp focus and I'm quickly frustrated when others can't do the same.

I met a number of bright dedicated researchers while volunteering for the Autism Speaks science board. Many of us continue to work together today, on government boards, with the World Health Organization (WHO), and with the International Society for Autism Research (INSAR), the professional society for autism researchers. Those other organizations have changed significantly in response to autistic input. We have a strong voice in creation of our government's autism plans. The WHO's International Classification of Functioning, Disability and Health (ICF) Autism Core Set recognizes both disability and exceptionality in us, thanks 
to autistic input (http://jerobison.blogspot.com/2018/04/autism-abilitydisability-and-icf-core.html). INSAR has encouraged making autistic people research collaborators. American public health agencies do the same. They expand their embrace of the community every year.

Since my departure Autism Speaks has seen considerable upheaval. Liz Feld left, followed by Rob Ring. Mrs. Wright passed away in 2016 and her husband resigned his position a short while later. The organization's funding of research has dropped these past few years.

Two years after my resignation Autism Speaks announced Stephen Shore and Valerie Paradiz were joining the organization's board. They were actual autistic people with a say in the group's governance. While I applaud them for doing that, I'm still waiting for substantive autistic-led initiatives from the organization.

Elsewhere in the autism community, there is an evolving and sometimes heated dialogue about who should speak for autistic people. For the last few decades advocacy has been the province of parents, grandparents, and professionals of various stripes. They were the ones who rose up and demanded services in response to the wave of new diagnoses beginning in the 1990s.

Today the kids they advocated for have grown up, and many are finding their voice. One principal venue for autism advocacy is now the Interagency Autism Coordinating Committee (IACC), which produces the strategic plan for autism for the US government. IACC guides NIH, CDC, Defense and other government agencies as well as private groups. At first IACC's advisers were autism researchers, clinicians, and parents. For the past decade, IACC has also had actual autistic people as members. I was appointed in 2011 and continue to serve as of this writing.

At IACC meetings I routinely see differences of opinion between nonautistic parents and actual autistics. The conversation often turns to who should have the primary voice, and I see that it's very hard for non-autistic parents to let go. Yet I feel that is what must happen. Adults speak for themselves in all other walks of life. Autism is a lifelong condition, not a childhood disorder (as was once thought). Autism research, therapy, and policy should be guided principally by autistic adults. It's that simple. 
Elsewhere in society we accept the idea that anyone who speaks for a group should be a member of the group. By that reasoning any spokesperson for autistic people should be autistic. A parent can certainly speak for autism parents, but that is a different community and like all parents, their wants and needs are sometimes at odds with those of their children, particularly as the children grow up.

The day may come that Autism Speaks is led by actual autistic people. I hope that happens. Alternately, Autism Speaks may remain primarily a parent advocacy group for families with young children on the autism spectrum. That is effectively what they were in the beginning, and where they may be most at home.

Actual autistic people seem more drawn to autistic-founded and autistic-led groups like the Autistic Self Advocacy Network (ASAN) and I expect they will grow more powerful as their membership grows and ages.

I joined the Autism Speaks science board in the hope I could help move their science in a direction that would be more beneficial to autistic people. At the time I thought their legacy would be good autism science. I left the Autism Speaks science board because of their hurtful depictions of autism and autistic people. Autism Speaks did not make a huge mark in science, and with drops in funding their significance in that world has diminished. It's toxic rhetoric that has become the organization's legacy.

Meanwhile we autistic people are still here. We're not missing, and we're not lost. Monsters will not take us, because we are strong. When it comes to policy, parents and clinicians certainly have a say, and deserve a seat at the table, but the table rightly belongs to us. We are autistic people.

\section{References}

1. Attwood, T. (1997). Asperger syndrome: A guide for parents and professionals. London, UK: Jessica Kingsley Publishers.

2. Lord, C., Risi, S., Lambrecht, L., Cook, E. H., Jr., Leventhal, B. L., DiLavore, P. C., et al. (2000). The autism diagnostic observation schedule-generic: A standard measure of social and communicative deficits associated with the 
spectrum of autism. Journal of Autism and Developmental Disorders, 30(3), 205-223.

3. Robison, J. E. (2007). Look me in the eye: My life with Asperger's. New York, NY: Crown/Archetype.

4. Tammet, D. (2007). Born on a blue day. London, UK: Hodder.

5. Grandin, T., \& Scariano, M. M. (1986). Emergence: Labelled autistic. Novato, CA: Arena Press.

6. Williams, D. (1992). Nobody, nowhere: The extraordinary autobiography of an autistic. New York: Times Books.

7. Shore, S. M. (2003). Beyond the wall: Personal experiences with autism and Asperger syndrome. Shawnee Mission, KS: AAPC Publishing.

8. McCarthy, J. (2007). Louder than words: A mother's journey in healing autism. New York, NY: Plume.

9. Autism Speaks. (2009). I am autism. Retrieved March 1, 2019 from https:// www.youtube.com/watch?v=9UgLnWJFGHQ\&t=14s.

Open Access This chapter is licensed under the terms of the Creative Commons Attribution 4.0 International License (http://creativecommons.org/licenses/by/ $4.0 /$ ), which permits use, sharing, adaptation, distribution and reproduction in any medium or format, as long as you give appropriate credit to the original author(s) and the source, provide a link to the Creative Commons license and indicate if changes were made.

The images or other third party material in this chapter are included in the chapter's Creative Commons license, unless indicated otherwise in a credit line to the material. If material is not included in the chapter's Creative Commons license and your intended use is not permitted by statutory regulation or exceeds the permitted use, you will need to obtain permission directly from the copyright holder. 